\section{Similarity between p15E of murine and feline leukaemia viruses and p21 of HTLV}

SIR - Retroviral infections of a number of animal species are frequently associated with immunosuppression. The hydrophobic retroviral transmembrane protein p15E is highly conserved among type $C$ and type D retroviruses ${ }^{1}$. This protein may contribute to the immunosuppression associated with retroviral infections since it inhibits in vitro lymphocyte transformation in $\operatorname{man}^{2}$, cats ${ }^{3}$ and mice ${ }^{4}$ and increases tumour incidence in cats given feline sarcoma virus ${ }^{5}$. The mechanism for the inhibition of human lymphocyte transformation by $\mathrm{p} 15 \mathrm{E}$ was shown to be due to suppression of interleukin-2 (IL-2) production ${ }^{6}$. We have demonstrated in vitro suppression of human monocyte function ${ }^{6}$ and in vivo inhibition of murine macrophage accumulation to inflammatory foci by $\mathrm{p} 15 \mathrm{E}$ from murine leukaemia virus $(\mathrm{MuLV})^{7}$ or by tumour-associated proteins which are antigenically related to $15 \mathrm{E}^{6,8}$.

Human T-cell leukaemia-lymphoma virus (HTLV) is the designation for a family of T-lymphotropic, exogenous type $C$ retroviruses which have been isolated in a number of countries ${ }^{9-13}$. These viruses have been linked as aetiological agents to certain types of leukaemias and lymphomas and to the acquired immunodeficiency syndrome (AIDS) $^{14-16}$. It has recently been reported that the polymerase gene products of HTLV, MuLV and avian Rous sarcoma virus are partially homologous in their amino acid sequence ${ }^{17}$. Since immunosuppression often accompanies the HTLVassociated $\mathrm{T}$-cell malignancies and is characteristic of AIDS, we hypothesized that HTLV-viruses might have, in addition to their lymphocytopathic effects, other features in common with immunosuppressive MuLV and feline leukaemia viruses (FeLV). We therefore compared the amino acid sequences for p15E of Friend ${ }^{18}$, Moloney ${ }^{19}, \mathrm{AKV}^{20}$, and Gross ${ }^{21}$ murine leukaemia viruses (FLV, MoLV, $A K V, G L V), F_{L V}{ }^{22}$, and mink-cell focusforming viruses of Moloney ${ }^{23}$ and $\mathrm{AKR}^{24}$ origin (MMCF, AMCF) with the sequences of the envelope proteins of HTLV-I ${ }^{25}$ and HTLV-II ${ }^{26}$. The sequences were analysed for homology using the PROTHOM computer program developed by Fristensky et al. ${ }^{27}$.

As shown in the figure above there is a significant degree of homology $(73 \%)$ between the various $\mathrm{p} 15 \mathrm{E}$ proteins and HTLV-1 and HTLV-II which occurs in a 26-amino acid sequence located in the p21 region of HTLV. It is particularly noteworthy that the first 10 amino acids in this region are identical and that this region of homology occurs in almost the same region of the p15E and p21 molecules. The homology begins at residue 70 in p15E and at residue 377 of the HTLV-I envelope protein and at residue 373 of the HTLV-II envelope protein which both correspond to

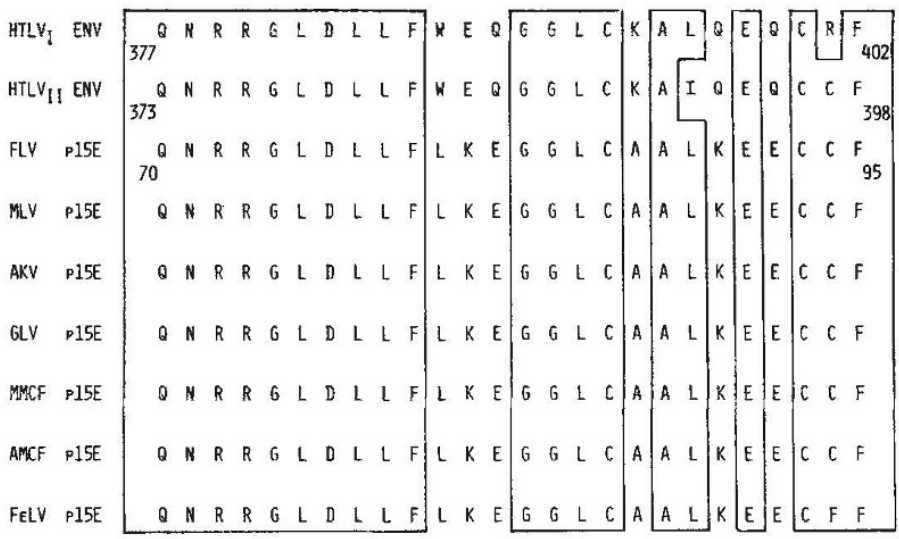

Amino acid sequence homology between 21 of HTLV-I and HTLV-II and p15E of murine and feline leukaemia viruses. Residue 377 of the RTLV-I envelope and 373 of the HTLV-II envelope both correspond to residue 65 of the p21 protein.

residue 65 of the $\mathrm{p} 21$ transmembrane protein ${ }^{26}$

The significance of such a well conserved region occurring in murine, feline, and human retroviruses is not yet clear. However, since dramatic immunosuppression is often associated with these viruses and purified $\mathrm{p} 15 \mathrm{E}$ is immunosuppressive in a variety of systems, it will be particularly important to determine whether p21 of HTLV can also inhibit immune functions. GeORGE J. Cianciolo ROBERT J. KIPNIS

RALPH SNYDERMAN

Howard Hughes Medical Institute,

Department of Medicine,

Duke University Medical Center,

Durham,

North Carolina 27710, USA

1. Thiel, H.-J., Broughton, E.M., Matthews, T.J., Schafer, W. \& Bolognesi, D.P. Virology 111, 270-274 (1981)

2. Copelan, E.A. et al. J. Immun. 131, 2017-2020 (1983).

3. Mathes, L., Olsen, R.G., Hebebrand, L.C., Hoover, E.A. \& Schaller, J.P. Noture 274, 687-689 (1978).

4. Fowler, A.K., Twardzik, D.R., Reed, C.D., Weislow, O.S \& Hellman, A. Cancer Res. 37, 4529-4531 (1977).

S. Mathes, L.E. et al. Cancer Res. 39, 950-955 (1979).

6. Cianciolo, G.J., Hunter, J., Silva, J., Haskill, J.S. \& Snyderman, R. J. clin. Invest. 68, $831-844$ (1981).

7. Cianciolo, G.J., Matthews, T.J., Bologonesi, D.P. \& Snyderman, R. J. Immun. 124, 2900-2905 (1980).

8. Cianciolo, G.J., Lostrom, M.E., Tam, M. \& Snyderman, R. J. exp. Med. 158, 885-900 (1983)

9. Poiesz, B.J., Ruscetti, F.W., Gazdar, A.F., Bunn, P.A., Minna, J.D. \& Gallo, R.C. Proc. natn. Acad. Sci. U.S.A $77,7415-7419$ (1980)

10. Gallo, R.C. et al. Cancer Res. 43, 3892-3898 (1983).

11. Haynes, B.F. et al. Proc. natn. Acad. Sci U.S.A. 80, 2054-2058 (1983)

12. Miyoshi, l. et al. Nature 296, 770-771 (1981)

13. Popovic, M. et al. Science 219, 856-859 (1983).

14. Gallo, R.C. et al. Science 224, 501-503 (1984).

15. Popovic, M., Sarngadharan, M.G., Read, E. \& Gallo, R.C. Science 224, 497-500 (1984)

16. Sarngadharan, M.G., Popovic, M., Bruch, L., Schupbach J. \& Gallo, R.C. Science 224, 506-508 (1984).

17. Patarca, R.\& Haseltine, W.A. Nature 309, 288 (1984)

18. Koch, W., Hunsmann, G. \& Fredrich, R. J. Virol. 45 1-9 (1983).

19. Shinnick, T.M., Lerner, R.A.\& Sutcliffe, J.G. Nature 293 543-548 (1981)

20. Lenz, J., Crowther, R., Straceski, A. \& Haseltine, W. J. Virol. $423519-529$ (1982).

21. DesGroseillers, L., Villemur, R. \& Jolicoeur, P. J. Virol. 47, 24-32 (1983).

22. Elder, J.H. \& Mullins, J.I. J. Virol. 46, 871.880 (1983).

23. Bosselman, R.A., van Straaten, F., Van Beveren, C. Verma, I.M. \& Vogt, M. J. Virol. 44, 19-31 (1982).

4. Kelley, M. et al. J. Virol. 45, 291-298 (1983).

25. Seiki, M., Hattori, S., Hirayama, Y.\& Yoshida, M. Proc natn. Acad. Sci. U.S.A. 80, 3618-3622 (1983).

26. Sodroski, J, et al. Science 225, $421-424$ (1984).

27. Fritensky, B., Lis J. \& Wu, R. Nucleic Acids Res. 10, $6451-6463$ (1982).

\section{Islet activating protein analogous to $\mathrm{p} 21$ ras?}

SIR - In a recent article on mutant ras protein and cell transformation, Rob Newbold considered the significance of new findings about p21 ras function and activation. In particular, similarities between $\mathrm{p} 21$ ras and the guanine nucleotide binding proteins which are responsible for stimulation and inhibition of adenylate cyclase were emphasized and an analogy drawn with the action of cholera toxin on $\mathrm{G}_{\mathrm{S}}$ protein GTPase, implying that $\mathrm{p} 21$ ras might act in an analogous manner to cholera toxin, which exerts a strong proliferative stimulus on certain mammalian cells in culture.

I suggest that the analogy with cholera toxin is dubious in view of the fact that rat cells transformed by Kirsten sarcoma virus have been shown to contain less cyclic AMP and lowered adenylate cyclase activity. Therefore a closer analogy may be with the action of islet activating protein which reacts with $\mathrm{Gi}$ proteins to inhibit adenylate cyclase and reduce cyclic AMP. This would imply that decreased cyclic AMP assists proliferation.

R. K. RALPH

Department of Cell Biology,

The University of Aukland,

1. Newbold, R. Nature 310, 628-629 (1984). M. Cell 1, 59-64 (1974)

3. Anderson, W. B., Galio, M. Pastan, I J biol. Chem. 249, $7041-7048$ (1974)

4. Gilman, A. Cell 36, 1577-1579 (1984).

\section{Heritable IQ - a reason to bother}

SIR - The recent article from Teasdale and Owen ${ }^{1}$ prompts one to wonder about IQ genes. If intelligence is substantially heritable, is it determined by genes in a positive sense, such that better allelic combinations of IQ genes produce more intelligent people? This may seem to be the most parsimonious explanation, but parsimony is in the eye of the beholder.

That simple genetic mechanisms can account for conspicuously low IQ stirs no
Private Bag, Aukland, New Zealand

2. Carchman, R.A., Johnson, G.S., Pastan, I \& Scolnick, E. 